\title{
Legal and Institutional Challenges Facing the Somali Regional State in the Implementation of Environmental Impact Assessment
}

\author{
Melaku Gezahegn Mekonnin \\ School of Law, Hawassa University, Hawassa, Ethiopia \\ Email: gezahegn mela@gmial.com
}

How to cite this paper: Mekonnin, M. G. (2019). Legal and Institutional Challenges Facing the Somali Regional State in the Implementation of Environmental Impact Assessment. Beijing Law Review, 10, 455-473. https://doi.org/10.4236/blr.2019.103027

Received: February 19, 2019

Accepted: May 31, 2019

Published: June 3, 2019

Copyright $\odot 2019$ by author(s) and Scientific Research Publishing Inc. This work is licensed under the Creative Commons Attribution International License (CC BY 4.0).

http://creativecommons.org/licenses/by/4.0/

(c) (i) Open Access

\begin{abstract}
Ethiopia is a federal country wherein all regional states making the federation are required to establish an independent regional environmental agency or designate an existing agency to carry out environmental protection and management duties. In line with this, the Ethiopian Somali Regional state (one among of the federating states) has enacted legislations and established institutions designated for the implementation of Environmental Impact Assessment. This research mainly aims to show whether the required legal and institutional frameworks related with EIA are established in the region through systematic analysis of legal documents. Moreover, interviews were conducted with the concerned regional authorities and data gathered were qualitatively described to show implementation of EIA in the region. Accordingly, the proper analysis of legislations and interviews conducted reveals the fact that beyond the positive progress achieved, there are legal and institutional gaps affecting the implementation of EIA in the region. Lack of a directive listing projects requiring EIA and those that do not and a guideline that determines categories of public instruments to be initiated by the regional organs are among the major challenges facing the region in the implementation of EIA. Institutionally too, the regional environmental authority is not staffed with required EIA experts and is not cascaded down to other major towns of the region as is required by the law. Lack of coordination among the regional institutions, unavailability of qualified environmental experts, consultants and meaningful participation of the public during EIA preparation are also the basic challenges affecting the implementation of EIA. Hence, so as to properly integrate environmental concerns into developmental aspiration of the region, it is argued in this paper that challenges related with legislations and institutional gaps need to be properly addressed by the concerned regional authorities.
\end{abstract}




\section{Keywords}

Environmental Impact Assessment, Horizontal Coordination, Public

Participation

\section{Introduction}

The current governmental structure in Ethiopia was established on 21st August 1995, when the country's Constitution was formally adopted, which established a federal structure and a parliamentary system of government (Federal Democratic Republic of Ethiopian Constitution, Article 1 and 45, 1995). Accordingly, there are 9 regional states and two cities. Addis Ababa and Dire Dawa are technically "chartered cities", each governed by their own councils (Federal Democratic Republic of Ethiopian Constitution, Article 47, 1995). Immediately below the states in the hierarchy, there sits the "woredas" (district) and within each woreda, there are a number of kebeles (sub district), which represent the smallest unit of local government.

Both the Federal Government and the States were given considerable legislative, executive and judicial powers under the 1995 Constitution, which also ensured the decentralization of many political, fiscal and administrative powers to State level. While the power to enact laws related with the utilization and conservation of land and other natural resources is reserved to the federal government, the right to administer land and other natural resource in accordance with the federal laws is vested to the regional states (Federal Democratic Republic of Ethiopian Constitution, Article 55(5), 52(d), 1995). The Constitution also states that "all powers not expressly given to the Federal Government and the States are reserved to the States" (Federal Democratic Republic of Ethiopian Constitution, Article 52, 1995).

The Ethiopian Somali Regional State is one among the 9 member states of the Federal Democratic Republic of Ethiopia (Federal Democratic Republic of Ethiopian Constitution, Article 47, 1995). The region is the second largest regional state in the country next to Oromia Regional State with total area coverage of $350,000 \mathrm{~km}^{2}$. It is located in the east and south-east of the country and lies between 4 and 11 degrees north latitude and 40 and 48 degrees east longitude. The region shares borders with Somalia to the east and southeast, Kenya to the south and Djibouti to the north and with Oromiya Region to the west. The climate is arid in most parts of the Region and weather is therefore hot in most parts of the year, with mean temperatures ranging from $18^{\circ} \mathrm{C}$ to $45^{\circ} \mathrm{C}$. Temperatures are cooler in areas of high altitudes like Fafan Zone and of parts of Afder zone (example, Elkare) and hotter is in the areas around the main rivers of the Region. Annual rainfall ranges $150 \mathrm{~mm}$ in the low lying areas of the Region to $660 \mathrm{~mm}$ received in high altitude areas.

This article will try to assess implementation of Environmental Impact As- 
sessment (EIA) in the Somali region of Ethiopia. Accordingly, the first part of this article provides an overview of historical development of EIA. Basic legislation dealing with EIA at the federal and the Ethiopian Somali regional state will be briefly canvassed under the next part. Following, implementation of EIA and issues related with institutional set up of implementing organs and their coordination in implementing EIA, participation of the public during EIA and the manner of preparation of EIA in the region will be thoroughly analyzed. Finally, the paper will come to an end with conclusion.

\section{Historical Overview of EIA and its Emergence in Ethiopia}

In the past, 'economic growth and its ecological consequences have been treated as totally separate concepts within the broader paradigm of development (Alam, 2008). Attaining development through economic growth was seen as a panacea for each problem that the world was facing, ignoring the ecological impact that economic growth poses on the environment. In Ethiopia too, much emphasis has been given to achieve economic development and the ecological consequences of such projects were not properly considered. These development projects had in fact caused damage to the environment and to the public health (Teklemichael, 2008). However, as time went by, rising world poverty, economic inequalities, and the depletion of finite natural resources have challenged the traditional development paradigm that limitless economic growth is a panacea to all of humanity's most pressing problems (Alam, 2008). Currently, there is a wider consensus on the fact that economic growth without the necessary sensitivity to environmental quality is not sustainable over the longer run.

It is based on such wider belief that the need for integrating environmental consideration in to economic and social activities gives rise to the emergence of the concept of Sustainable Development and to its main tool, Environmental Impact Assessment (EIA). The International Association for Impact Assessment (IAIA) recognized EIA as "the process of identifying, predicting, evaluating and mitigating the biophysical and other relevant effects of development proposals prior to major decisions being taken and commitments made" (International Association for Impact Assessment, 1999). In fact, EIA is now an established international and domestic legal technique for integrating environmental consideration in to socio economic decision needs which mainly describes a process that produces a written instrument (Sands, 2003).

Historically, the United States of America is noted as the first country to adopt national EIA law (the National Environmental Policy Act of 1969 effected on (January 1, 1970) (Bodensky, 2010). NEPA requires implementation of EIA for federally funded or supported large scale projects in the US that were likely to have environmental effects; and it obliges federal authorities in the United States to take decisions on their activities only with prior knowledge of their likely environmental consequences (Singh, 2007). Then on wards, the practice of EIA has been widespread in the rest of the world and has become an important model for 
EIA systems of other countries.

In Ethiopia, though the practice of EIA was limited to some sectors and donor driven, the concept of EIA was introduced in the country in 1980's by the water resources development projects assisted by United Nations Development Programe and World Health Organization. Later on, this practice evolved into a formal requirement in international donor assisted and financed projects in various sectors. The former Ethiopian Valleys Development Authority was the first national institution to incorporate EIA into its activities. The authority developed its own specific guideline for the application of EIA in pre-feasibility studies of potential medium-scale irrigation projects. As is stated above, though such practices were limited in scope and donor driven, they have nonetheless contributed to the emergence of the system of EIA that exists in the country.

\section{Overview of EIA Legislation under the Federal Laws of Ethiopia}

\subsection{EIA under the FDRE Constitution}

The Federal Democratic Republic of Ethiopian Constitution, which was proclaimed in the year 1995, has envisages basic and comprehensive principles and guidelines for environmental protection needs. For example, it boldly states that everyone has the right to live in a clean and healthy environment and the Government will make every effort to provide such an environment (Federal Democratic Republic of Ethiopia Constitution, Article, 44 and 92, 1995). It is also duly recognized in the constitution that the design and implementation of programmes and projects of development shall not damage or destroy the environment (Federal Democratic Republic of Ethiopia Constitution, Article 44 and 92, 1995). The need for public participation in the planning and implementation of environmental policies and projects that affect them directly is also recognized in the constitution (Federal Democratic Republic of Ethiopia Constitution, Article, 92(3), 1995). The constitution can thus be taken as envisaging the basic essence of EIA as it urges for the right to live in a clean and health environment, the need for public participation and the need for integration of environmental consideration in the developmental aspiration of the country.

\subsection{EIA under Environmental Policy of Ethiopia}

The first comprehensive statement of Environmental Policy for the Federal Democratic Republic of Ethiopia was approved by the Council of Ministers in the year 1997. The policy and strategy of the document was in fact the findings and recommendations contained in Volume II of the Conservation Strategy for Ethiopia. The Environmental Policy is predicated on a growing concern for the degradation of the natural resource base, and takes into account how that base is affected by, and affects, the overall productivity of the agriculture sector in the country. The overall policy goal is to improve and enhance the health and quality of life of all Ethiopians and to promote sustainable social and economic de- 
velopment that meets the needs of the present generation without compromising the ability of future generations to meet their own needs.

The policy states that every person has the right to live in a healthy environment and when a compromise between short-term economic growth and long-term environmental protection is necessary, then development activities shall minimize degrading and polluting impacts on ecological and life support systems. It also underline the fact that environmental impact assessments consider not only physical and biological impacts but also address social, socio-economic, political and cultural conditions. The policy enunciate the fact that public consultation to be an integral part of EIA and ensure that EIA procedures make provision for both an independent review and public comment before consideration by decision makers (The Environmental Policy of Ethiopia, 1997).

\subsection{Environmental Protection Authority Proclamation No. 9/1995 and No. 295/2002}

The first environmental authority of the country was established in the year 1995 as an autonomous public institution of the Federal Government through Proclamation No. 9/1995. The main objective for the establishment of the authority was to ensure that all matters pertaining to the country's social and economic development activities are carried out in a manner that will protect the welfare of human beings as well as sustainably protect, develop and utilize the resource bases (Federal Democratic Republic of Ethiopia Constitution, Proc. No. 9/1995, Article 5, 1995). Even if, there is no specific mention of the term EIA in the proclamation, one can however note the fact that the authority was under obligation to ensure that the countries aspiration to achieve economic development should take in to consideration the welfare of human beings and the sustainability of natural resource base of the country. It is also specifically mentioned in the proclamation that the authority should prepare a directives and systems necessary for evaluating the impact of social and economic development projects on the environment and should follow up and supervise their implementation (Federal Democratic Republic of Ethiopia Constitution, Proc. No. 9/1995, Article 6(2), 1995). This is a clear endorsement of the need to introduce a system of environmental impact assessment in the country so that the adverse impact of developmental projects on the environment could be minimized or could be averted to the extent possible.

Later on, proclamation No. 9/1995 was repealed and replaced by proclamation No. 295/2002, Environmental Protection Organs Establishment Proclamation. In this proclamation too, the environmental protection authority is mandated to come up with strategies, laws and standards that foster economic development and enhance the welfare of humans and safety of the environment. Unlike that of its predecessor, however, Proc. No. 295/2002, clearly mandated the authority to establishment a system for environmental impact assessment of public and private projects, as well as social and economic development policies, strategies, laws, and programmes (Ethiopian Environmental Protection Organs Establish- 
ment Proclamation, Proc. No. 295/2002, Article 6(2), 2002). The proclamation clearly shows the countries commitment to come up with a system of EIA that will help to predict, reduce and offset the negative consequences of development projects (both public and private projects) on the environment. Thought the basic principle of EIA was enshrined in the aforementioned legislations, it was in the year 2002 that Environmental Impact Assessment proclamation No. $299 / 2002$ of the country was enacted.

\subsection{Enactment of Environmental Impact Assessment Proclamation No. 299/2002}

Seven years after the enactment of the FDRE constitution, Ethiopia has issued its EIA proclamation No. 299/2002 in the year 2002. The proclamation is divided in to seven parts dealing with different interrelated issues. Among those basic issues is the one dealing with respective power and responsibility of the federal and regional governments with regard to EIA. At the federal level, the environmental authority is responsible for the evaluation and monitoring of implementation of EIA for those projects which are subject to licensing, execution or supervision by a federal agency or when the EIA report is to produce trans-regional impact (Ethiopian Environmental Impact Assessment Proclamation, Proc. No. 299/2002, Article 14(1), 2002). The respective regional environmental agencies on the other hand, are responsible for the evaluation, authorization and monitoring of EIA for projects subject to regional licensing, execution and supervision and for those projects unlikely to produce trans-regional impact (Ethiopian Environmental Impact Assessment Proclamation, Proc. 299/2002, Article 14(1), 2002).

The proclamation mainly addresses issues of what should appropriate organs do if they realize the occurrence of unforeseen facts of serious implication of a project after submission of the EIA report. In this regard, the law authorizes the appropriate federal environmental protection authority and regional environmental agencies to order revision of the study report or they can order the report to be redone again (Ethiopian Environmental Impact Assessment Proclamation, Proc. 299/2002, Article 11, 2002). The proclamation also deals the manner how the authority and regional environmental agencies can conduct monitoring of approved projects. Accordingly, the law authorizes them to monitor the implementation of an authorized project so that they can check whether the proponent is in compliance with all commitments made by and obligation imposed during authorization. In case the proponent is not in compliance with his commitment and failed to respect the obligation imposed on him, the appropriate environmental organs are given a power to order a proponent to undertake specified rectification measure and in case he failed to do so, the project license given for the proponent could be suspended or cancelled (Ethiopian Environmental Impact Assessment Proclamation, Proc. 299/2002, Article 12 (2 and 3), 2002).

With regard to public instrument, it is specifically stated in the proclamation 
that the authority shall issue a guideline to determine the category of public instruments that are likely to entail significant environmental impact and the procedure of their impact assessment (Ethiopian Environmental Impact Assessment Proclamation, Proc. 299/2002, Article 13(2), 2002). All government organs which will initiate or prepare public instruments subjected to EIA are required to ensure that EIA is properly carried out and should collaborate with the authority for the evaluation of the EIA report of the instrument (Ethiopian Environmental Impact Assessment Proclamation, Proc. 299/2002, Article 13, 2002). Proper analysis of legislations at the federal level reveals the fact that the need to integrate environmental consideration in to the development aspiration of the country is embedded under the aforementioned legislations and regional governments are also mandated to enact EIA related legislation in accordance with the federal laws to be applicable in their particular region.

\section{Legal and Institutional Frame Work of EIA in the Ethiopian Somali Regional State}

\subsection{Legal Framework of EIA in the Ethiopian Somali Regional State}

As the cumulative reading of the preamble of the federal EPA establishment proclamation No. 295/2002 and Article 15 of the same proclamation clearly states, each regional state is required to establish an independent regional environmental agency or designate an existing agency to carry out environmental protection and management duties. It is thus based on the above general provisions an assessment will be made whether the ESRS has enacted the required legislation necessary for the establishment of an independent environmental agency or designates an existing agency for the implementation of EIA in the region.

\subsubsection{EIA under the Revised Somali Regional State Constitution}

The Ethiopian Somali Regional State Revised Constitution, which was ratified in the year 1994, was the first legal instrument that tries to address environmental protection issues in the region. It is specifically stated in the constitution that the regional government is duty bound to enable all residents of the region to live in a clean and healthy environment and that any economic development measures to be carried out in the region should not damage the environment. The regional residents are also given the right to participate in any policy or programme which is related with environmental protection endeavor of the region. The constitution also imposes obligation on both the regional state and the residents of the region to protect the environment and more specifically to do whatever is necessary to avert desertification. Even if, the constitution does not specifically mention the need to conduct EIA, it can be said that it clearly envisages the need to integrate environmental consideration into development aspiration of the region which in fact is the very essence of EIA. 


\subsubsection{The Enactment of the ESRS Environmental Protection Natural Resources and Energy Development Utility Proclamation No. $92 / 2003$}

The Ethiopian Somali regional state has enacted its Environmental Protection Natural Resources and Energy Development Utility Proclamation No. 92/2003, in the year 2003. The proclamation is mainly devoted to establish an independent environmental protection utility of the region that can effectively discharge the responsibilities of the region with regard to environmental protection and energy development activities (The Somali Regional State Environmental Protection Natural Resources and Energy Development Utility Establishment, Proc. No. 92/2003, preamble, 2003). However, the regional environmental agency/department is merged with the Environmental Protection Natural Resources and Energy Development Utility of the region than being established as an independent environmental agency (The Somali Regional State Environmental Protection Natural Resources and Energy Development Utility Establishment, Proc. No. 92/2003, 2003).

The Utility is made to be accountable to the office of the regional president having its own legal personality and is responsible to issue based on the federal environmental policies, strategies and laws, the regional environmental policy, strategy and directives and follow their implementation (The Somali Regional State Environmental Protection Natural Resources and Energy Development Utility Establishment, Proc. No. 92/2003, Article 4, 2003). The utility is responsible to coordinate the regional environmental protection bodies and provide capacity building support, issue publications to raise public awareness on environmental issues, make studies that promote energy and mineral development (The Somali Regional State Environmental Protection Natural Resources and Energy Development Utility Establishment, Proc. No. 92/2003, Article 7(1-24), 2003). The proclamation thus has properly establishes a utility having a number of powers and duties with regard to ensuring that the economic development activities to be carried out in the region should not affect the well being of the society and the regional environment.

\subsubsection{Enactment of the Ethiopian Somali Regional State Environmental Impact Assessment Proclamation No. 111/2004}

Just one year after the establishment of the utility, the Somali Regional State Council enacted the regional Environmental Impact Assessment Proclamation No, 111/2004. This in fact is a great move taken by the regional government for the implementation of EIA in the region. The proclamation is divided in to six parts totally envisaging 22 Articles. It is worth noting that the term 'utility' which is used to refer the environmental protection he fact natural resource and energy development utility under proc. $92 / 2003$ is replaced by the term 'authority' in the regional EIA proclamation No. 111/2004. The regional EIA proclamation also defines "licensing agency" as any regional state organ empowered by law to issue an investment permit or a trade or operating license or a work permit or to register a business organization, as the case maybe (The Somali Re- 
gional State Environmental Impact Assessment Proclamation, Proc. No. 111/2004, Article 2(5), 2004). Such licensing agencies are prohibited in order not to issue an investment permit or a trade or operating licenses for any projects unless the environmental agency of the region has authorized its implementation (The Somali Regional State Environmental Impact Assessment Proclamation, Proc. No. 111/2004, 3(3), 2004).

Coming to another pivotal issue, Article 3 of proc. No. 111/2004 states that no person is allowed to commence implementation of projects that require environmental impact assessment as will be determined by a directive to be issued by the cabinet of the regional government (The Somali Regional State Environmental Impact Assessment Proclamation, Proc. No. 111/2004, Article 19, 2004). The directive to be issued is required to categorize projects that will require environmental impact assessment and those that do not require its implementation (The Somali Regional State Environmental Impact Assessment Proclamation, Proc. No. 111/2004, Article 3, 2004).

In addition, Article 13(2) of the proclamation also requires the need to issue a directive that will specifically list or categorize public instrument that need to undergo through environmental impact assessment and those that do not need to undergo through environmental impact assessment (The Somali Regional State Environmental Impact Assessment Proclamation, Proc. No. 111/2004, Article 13, 2004). To this effect, any regional government organ which initiate a public instrument falling in a category that need to undergo through EIA system is mandatorily required to ensure the implementation of EIA and should collaborate with the environmental protection mines and energy development authority of the region (The Somali Regional State Environmental Impact Assessment Proclamation, Proc. No. 111/2004, Article 13(3 and 4), 2004).

Even if the regional EIA proclamation No. 111/2004 unequivocally requires the regional cabinet and the Utility to issue regulation and directives respectively, neither the regional cabinet nor the Utility have issued the required detail laws. Asked why the required regulation and directives have not been issued regardless of what the law requires, Mr, Ahmed Aden, who is the head of the environmental agency replied that even if the Utility has finalized the preparation of draft directive that lists projects requiring EIA and those that do not and sent it to the regional Justice bureau for comment, so far, the bureau has not sent its comments and the directive is not issued ${ }^{1}$. The interviewee also noted that even if the proclamation also requires the issuance of EIA directive for public instruments to be prepared by the regional government organs, so far such directive is not even prepared in a draft level ${ }^{1}$.

Asked about how in default of such directives the authority is carrying out its responsibility, Mr. Ahmed Aden, replied that the Utility uses a guideline for reviewing Environmental impact study reports which is directly adopted from the federal EPA guidelines ${ }^{1}$. The head of the agency also replied that the adopted ${ }^{1}$ Interview with Mr. Ahmed Aden Abdulahi, Head of the Ethiopian Somali Regional State Environmental Agency. (2017) 
guideline is in a draft stage which has no force of law. The guideline is mainly intended to overcome the real problems that are related with reviewing environmental study reports prepared by proponents of a project. Providing consistent approach for reviewing EIA in the region, ensuring that all relevant information has been analyzed and presented based on appropriate methodologies and making sure that the concerns of all stakeholders is taken in to account are among the major objectives of the guideline.

In order to understand how the agency is using the guideline, it is of a paramount importance to see the snap shot of the guideline. The guideline is divided in to four review guideline series. Namely; Review guideline series 1, guideline series 2 , review guideline series 3 and review guideline series 4 . Review guideline series 1 address the most fundamental issues with regard to how competent authorities review environmental impact study report. As such the approach's to be followed in reviewing the reports, structured questioners (checklists) for interpreting the information as well as background information of the suggested review criteria for compelling the review comments are included in it. Review guideline series 2 is mainly meant to provide information about the contents of the ESIA report and is intended to help the relevant authorities to pass timely and informed decisions by reviewing the ESIA report in detail. Review guideline series 3 on the other hand, comprises checklists that will help the authorities to know range of technical issues and sub issues that should be considered during evaluation of different development projects in any sector. Lastly, review guideline series 4 deals with adopted environmental criteria's that would help appropriate reviewers to determine the validity and accuracy of information's contained in the ESIA report and advise the concerned authorities whether a project should be allowed to proceed or not.

Moreover, the adopted guidelines comprises of three schedules that list projects requiring full EIA, partial EIA and that do not require EIA at all. Accordingly, schedule 1 lists projects which may have significant adverse environmental and social impacts and require full EIA. Schedule 1 also lists two categories of projects that should be reviewed and approved at the bureau-head office level and at the zonal level and major urban centers. This means that projects categorized under section 1, requiring full EIA, will be subjected to reviewing procedures by senior experts at Utility head level, while development projects requiring full EIA, but not listed under projects reviewing at head office level in section 1 and those projects listed under schedule 2, those requiring partial EIA will be reviewed and approved by experts at zonal level and major urban centers of the region. Finally, projects having no environmental impact and that do not require EIA are listed under schedule 3 of the adopted Somali regional state guideline. Thus, though the guideline has no binding status, the regional environmental department uses it to carry out its day to day activities.

The other worth nothing point with regard to the regional EIA proclamation is related with preparation of EIA. The proclamation stipulates that the duty to prepare EIA report by covering its cost lies on the shoulder of a proponent (The 
Somali Regional State Environmental Impact Assessment Proclamation, Proc. No. 111/2004, Art. 7, 2004). The proclamation oblige proponents to make sure that the environmental impact of a project is conducted and the EIA report is prepared by an expert who can fulfill any requirement to be specified by the EIA authority of the region (The Somali Regional State Environmental Impact Assessment Proclamation, Proc. No. 111/2004, Art. 7(2), 2004). However, so far, no such requirements or standards are set by the regional environmental authority against which consultants are going to be evaluated. In addition, as usually proponents are hired and paid by the proponent; consultants may be biased in favor of proponent's desire, believing that approval will lead to future work or other benefits. This is even what the regional environmental department admits by further stating that the regional environmental utility should come up with a directive that will set a requirement for any environmental consultants interested to engage in the service ${ }^{1}$. It is thus of imperative for the regional Utility to enact a directive that will set a criteria for licensing environmental consultant.

As is seen above, the legal frameworks that dictate implementation of EIA in the Ethiopian Somali regional state are properly enacted. However, as neither the directive nor the guideline required by the regional EIA proclamation have never been formally approved by the concerned regional bodies, the Utility must as soon as possible issue the regional EIA directive that would foster the implementation of EIA in the ESRS. Moreover, since the absence of a clear environmental policy could be a hindrance to the environmental protection endeavors, the environmental utility should as much as possible prepare the regional environmental policy and strategies.

\subsection{Institutional Framework and Horizontal Coordination of Stakeholders in the Implementation of EIA in the ESRS}

\subsubsection{Institutional Organization of the Regional Environmental Protection Natural Resources and Energy Development Utility}

In the year 2003, the ESRS has established its own Environmental Protection Natural Resources and Energy Development Utility through the enactment of Proclamation No.92/2003. The proclamation establishes an independent Utility which is accountable to the office of the regional president and having its own legal personality (The Somali Regional state Environmental Protection Natural Resources and Energy Development Utility Establishment, Proc. No. 92/2003, Art. 3, 2003). The "Utility", is established to organize the environmental protection activities, natural resource and energy development of the Somali Regional State (The Somali Regional state Environmental Protection Natural Resources and Energy Development Utility Establishment, Proclamation No. 92/2003, preamble, 2003).

As such, the department of environment in the utility is mandated to oversee the environmental protection efforts and the implementations of environmental impact assessment in the region. With regard to human resource, environmental impact assessment process requires multi-disciplinary professionals from vari- 
ous fields of studies like soil chemist, sociologist, social anthropologist, natural resource professional, civil engineer, sanitary engineer and chemical engineer (Tesfaye, 2012). At the national level, the Addis Ababa City Environmental Protection Authority requires seven professionals to review EIA report. However, there were only six professionals: a soil chemist, an environmentalist, a sociologist and social anthropologist, a natural resource professional, and a chemical engineer (Tesfaye, 2012). The authority however, has no professional in areas of civil engineer and a sanitary engineer that could properly contribute much in the proper assessment of EIA submitted to the authority.

Coming to the ESRS context, even if the head of environmental department of the region properly recognizes the need to have multi disciplinary professions from various field of studies to review EIA reports, he noted that there are only four employees in the agency that would examine EIA report submitted to the utility $^{1}$. Even those employees are not university graduates and have no unique professional qualification required for the proper review of EIA reports except training that they got from the Federal Environmental Authority.

The other acute problem is related with the structure and level of experts mandated to review EIA reports in the region. As has been discussed above, the draft EIA guideline of the region mandated senior experts at utility head office level to review projects requiring full EIA under schedule 1. Moreover, the guideline mandated experts at zonal level and major urban centers to review projects requiring full EIA reports but not listed under schedule 1 and those projects listed under schedule 2, requiring partial EIA review. The guideline thus clearly requires the availability of EIA experts at the Utilities head office level in Jigjiga town, in each zonal town of the region and in major urban towns of the region (Gode, Deghabour, Kebridahar). One can also easily understand from the guideline that the necessary institutional structure that will enable experts to properly carry out their responsibilities must be fulfilled.

Thought this is what the guideline requires, so far, EIA experts (save the limitations that have been discussed above) are only available in the utilities head office level at Jigjiga Town. Moreover, such experts and the institutional set up necessary for the review of EIA reports, is nonexistent in the zonal and major urban towns of the region. Asked about what actual impact do the nonexistence of experts is exerting in the implementation of EIA in the region, Mr. Ahmed point out that even if the regional utility itself has acute shortage of EIA experts, it is compelled to assign these experts to different parts of the region to projects that could have been reviewed by the zonal and major urban experts themselves. He further noted that this has casted its own negative impact on the limited experts of the utility who are again responsible to review a number of projects listed under schedule 1 of the guideline. Hence, unless the required professionals are employed, and the institutional set up required for implementation of EIA is cascaded down to the level that the guideline requires, the regional governments endeavor to integrate environmental considerations in projects that might negatively affect the environment would not be realized. It is of an urgent necessity 
for the regional utility to establish the required institutional set up of environmental protection units in those zonal and major urban towns of the region as soon as possible.

\subsubsection{Horizontal Coordination of EIA Implementation in the Ethiopian Somali Regional State Organs}

The regional EIA Proclamation No. 111/2004 prohibits the regional licensing agencies (empowered to issue an investment permit or a trade or operating licenses for any projects) in order not to issue such licenses unless the regional environmental agency has authorized the implementation of a project (The Somali Regional State Environmental Impact Assessment Proclamation Proc. No. 111/2004, Article 3(3), 2004). The proclamation also obliges any regional state organ to ensure the implementation of EIA for public instruments that should undergo through EIA. Regional state organs are also required to collaborate with the regional Utility to enable the evaluation of the likely environmental impacts of any public instrument to be prepared by them (The Somali Regional State Environmental Impact Assessment Proclamation, Proc. No. 111/2004, Article 13(3 and 4), 2004).

At this spot, the first important issue that deserve due consideration is whether the regional licensing agencies are issuing an investment or trade license in conformity with the legal requirement on one hand and; the coordination that exist between the licensing agencies and the regional environmental authority on the other hand. It has to be however, noted here that the institutions dealt herein under are not the only one but are those which frequently undertake projects requiring EIA.

\section{a) Somali Regional State Investment Agency}

One among those licensing agencies actively engaged in authorizing investors to engage in the regional investment activities is the ESRS Investment Agency. In this regard, an assessment was made to figure out how the ESRS Investment Agency is issuing investment permit (in areas in which the agency is mandated by the law to issue the license) for investors desiring to invest in the region.

The ESRS investment agency was established in the year 2003 E.C. Ever since its establishment, the agency is issuing investment license to different investors desiring to invest in the region. Asked whether the agency has been so far assuring that investors are securing authorization from the regional environmental agency before issuing an investment permit, Mr. Beshir Hassen, head of the regional investment bureau representative, admitted that at the beginning of the establishment of the agency, investment permits were issued for investors without assuring that the project they came up with is environmental friendly and that the regional environment agency had given them an authorization to that effect ${ }^{2}$. However, he added that currently the agency put implementation of EIA as one procedural requirement to issue a license for any projects requiring im-

${ }^{2}$ Interview with Mr. Beshir Hassen, Head of Ethiopian Somali Regional State investment Bureau, Representative. (2017) 
plementation of EIA. According to him, the agency usually asks investors to bring a permit from the regional environmental authority that confirms their project is environmental friendly and EIA is conducted to this effect. Asked about how much the agency is committed to mandatorily require investors to bring a go ahead permit from the concerned regional body, the interviewee admitted the existence of lacunas in this regard. As to him, the basic problem is related with proponents who consider EIA as additional burden and unnecessary cost to their investment.

Even sometimes when investors are too hesitant to conduct EIA and when the project is significant to the region, the agency gives a license to those investors without acquiring a permit from the regional environmental authority ${ }^{3}$. Such practices are in fact inconsistent with what the regional EIA proclamation which obliges any licensing agencies in order not to issue licenses unless the regional environmental agency has authorized the implementation of a project. There is also weak coordination among the regional investment and environmental agencies with regard to EIA implementation. In this regard there is no formal or regular meeting between the agencies which is designed to settle some challenges and strengthen good experiences. There is also no mechanism that will bring about robust coordination among the agencies for effective implementation of EIA in the region.

One notable instance which shows lack of coordination and the issuance of investment permit without the authorization of a permit from the regional EIA authority should be noted here. In the year 2016 a certain investor has secured an investment permit for the manufacturing of Foam in Jigjiga town. Nevertheless, the factory got the license and has begun production without securing an authorization from the regional environmental agency. Asked about how this incident happened, Mr. Ahmed, head of the utility, stated that the agency had no prior knowledge about the factory and has not given any authorization to it. According to him, the agency knew about the foam factory from the complaints that it got from the resident of Jigjiga town who are living around the factory. $\mathrm{He}$ added that when the agency pay a visit to the factory, it realized the fact that the communities living around the factory are suffering a lot from a very bad smell which is the result of untreated chemical waste released from the foam factory. Though implementation of EIA for factories having disposal of chemical waste are mandatorily required to carry out EIA under the regional EIA guideline, the regional investment agency awarded a permit to the investor without the authorization of the environmental agency and against the clear requirement of the regional EIA proclamation and the EIA guideline.

\section{b) Somali Regional State Water Bureau}

Lack of preparation of EIA is not only manifested in projects to be carried out by private investors. Rather, such shortcomings are even more rampant in public instruments in projects to be carried out by regional government organs. In fact, ${ }^{3}$ Interview with Mr. Aden Abdi, Somali Regional State Investment Bureau Investment Promotion Process Owner. (2017) 
the regional EIA proc. No. 111/2004 obliges any regional state organ to ensure implementation of EIA for public instruments that should undergo through EIA. Regional state organs are also required to collaborate with the regional Utility to enable the evaluation of the likely environmental impacts of any public instrument to be prepared by them (The Somali Regional State Environmental Impact Assessment Proclamation, Proc. No. 111/2004, Article 13(3 and 4), 2004). In addition, Article 13(2) of the proclamation also requires the need to issue a guideline that will specifically list or categorize public instrument that need to undergo through environmental impact assessment and those that do not. To this effect, any regional government organ which initiate a public instrument falling in a category that need to undergo through EIA system is mandatorily required to ensure implementation of EIA and should collaborate with the environmental protection mines and energy development authority of the region.

Even if, the regional EIA proclamation No. 111/2004 requires the issuance of regional EIA guideline for public instruments to be issued by the regional environmental protection, natural resource and energy development authority, so far such directive is not even prepared in a draft level. Unavailability of the regional guideline coupled with lack of coordination among the regional environmental and other regional state lead to the non-existent of EIA assessment for public instruments. The Somali Regional State Water bureau, for example, constructs huge dams which the regional EIA guideline mandatorily requires preparation of EIA for projects to be carried out by proponents. However, the bureau rarely prepares public instruments for construction of huge water wells as well as dams constructed for clean drinking water and irrigation projects respectively ${ }^{4}$. After admitting that the bureau rarely conducts EIA assessment, an expert in the Water Bureau argues that getting safe drinking water for the people in Somali Regional State is of a top priority for the Bureau, and the feared deforestation which is argued to be caused by the water project constructions is imaginary ${ }^{5}$. This in fact is understandable as getting clean drinking water for the pastoralists of the region is a dire priority and as there are no guidelines that would help the bureau to screen those developments that need to undergo through EIA process and that do not. There is also no formal or informal mode of cooperation that is devised by the concerned organs.

For example, the ESRS water works construction enterprise is a responsible organ for the construction of dams for irrigation purpose under the supervision of the regional water bureau. Even if, the enterprise has successfully completed the construction of different size irrigation dams in different parts of the region, it had rarely prepared an EIA assessment and did not coordinate with the regional Utility before the implementation those projects ${ }^{3}$.

c) Somali Regional State Rural Road Authority

The Somali Regional State Rural Road Authority Bureau is also another public

${ }^{4}$ Interview with Mr. Abdiuragte Ahmed, Deputy Head of the ESRS Water Bureau. (2017)

${ }^{5}$ Interview with Mr. Waldi Elmi, expert at the regional Water Bureau. (2017) 
sector that carries out huge projects with great impacts on the environment, and which does not cooperate with the Utility in the implementation of these projects. The road projects which are implemented by the Rural Road Authority involve clearance and de-bushing of a large area. Previously, particularly in those times where the region was stricken by security problems, the Somali Regional state Rural Road Authority had been clearing land not only intended for the construction of the road, but a vast area of land were cleared for security purpose as well ${ }^{6}$. Currently however, as the security of the region is immensely improved and peace maintained, such practices are no more carried out ${ }^{5}$.

Asked about whether the regional rural road authority carry out EIA and coordinate with the regional Utility to this effect, Mr. Ahmed Nur, who is a planning officer of the authority confirmed that the authority does not carry out any EIA assessment to those rural projects that it is undertaking ${ }^{7}$. For example, the interviewee mentioned that even if in 2017 the authority had constructed 86 $\mathrm{Km}$ rural road from Fik to Segeg and $64 \mathrm{Km}$ rural road from Adigal to Dore respectively, the environmental consideration of the projects related with clearance and de-bushing of large areas were never studied. Moreover, the researcher learnt from the interview that there is no formal or informal means of coordination between the concerned regional environmental and road authority ever since the establishment of the two authorities. Of course, it is very obvious that the construction of infrastructure for the pastoralists' community contributes much to the growth of their economy, but the integration of environment with the road projects can sustain the lives of pastoralists' community without disrupting their way of life. In fact, the rural road authority projects such as that mentioned above are of mandatorily required to go through EIA and need to be approved at zonal level.

\section{Public Participation during EIA in the Ethiopian Somali Regional State}

The Ethiopian Somali Regional State EIA proc. No. 111/2004 clearly state that 'the authority shall make any environmental impact study report accessible to the public and solicit comments on it (The Somali Regional State Environmental Impact Assessment Proclamation, Proc. 111/2004, Art. 15(1), 2004). The regional EIA proclamation thus make it clear that any environmental impact assessment report prepared either by project proponents or government organs shall be made accessible to the communities likely to be affected by the implementation of the project. The regional environmental agency should also solicit comments on it and is required to take into account any public comments and expert opinions before passing a decision on the environmental study report submitted to it by the proponent (The Somali Regional State Environmental Impact Assessment Proclamation, Proc. 111/2004, Art. 15(2), 2004). No matter what the ${ }^{6}$ Interview with Engineer Abdi Mohammed, Chief Engineer at the Regional Rural Road Authority. (2017)

${ }^{7}$ Interview with Ahmed Nur, Planning Officer of the ESRS Rural Road Authority. (2017) 
decision could vary from approval to refusal of the implementation of the project at all, the agency should make sure that the comments given by the community likely to be affected by the project are incorporated into the EIA study report. The question that has to be raised in this regard is thus, what procedural requirements are provided by the law so that the public can participate within reasonable time and effectively and what does the practice looks like in this regard.

Indeed, public participation in EIA process can only be effectively implemented when the public is informed in an adequate, timely and effective manner. Even if, most countries do provide provisions that assure "timely notifications," but they do not provide legal guarantees that the public is notified in an "effective manner" (Justice and Environment ( $\mathrm{J}$ and E), 2008). As such, the public should not only be timely informed but also there should be a legal guarantee for effective notification. Moreover, as inaccessibility to documents can be great obstacle to public participation in the EIA process, the public should be allowed to get access to the EIA report as easy as possible. EIA legislations should thus provide sufficient time limit and effective manner of access to the EIA reports prepared by proponents.

Coming to the Ethiopian Somali Regional State Context, the proclamation and other subsidiary laws related with EIA are short of providing the manner how the public could get access to information about implementation of a project requiring EIA. There is also no timeline for the public to review and make comments on the EIA documents and any procedure for the public to submit grievances on the decision rendered by the authorities. The legislations are also short of providing the stages through which the public should involve in the implementation of EIA. For example, in Zimbabwe, public participation should occur at the scoping and preparation of the EIA terms of reference, preparation of EIA report and at the stage of government review of the EIA report (Abaza et al., 2004). This will enable both the public and the concerned authorities to know the stage in which participation of the public should take place. But, in the Ethiopian Somali regional state, as the stage through which the public should involve is not clearly provided, let alone the public, the authorities responsible for implementation of EIA do not know how and when the public should involve in EIA process. This in fact is the outcome of both lack of the authorities to actively monitor participation of the public in the EIA process and the shortcomings of the proclamation that failed to provide detail laws necessary for the implementation of public participation in the region. Hence, unless detail laws are introduced by the utility, public participation in the Ethiopian Somali regional state would be of rhetoric than a reality.

\section{Conclusion}

The Ethiopian Somali regional state has gone far in adopting EIA legislation relevant for preservation and protection of the regional natural resources. Nevertheless, beyond the positive progress achieved, there are legal gaps and institu- 
tional hurdles that need to be properly addressed for effective implementation of EIA in the region. The guideline prepared for reviewing environmental study reports to be prepared by proponents or consultants in 2012 has no binding effect as it is not issued at least in the form of a directive and approved by the utility as is required by the law. Moreover, even if the ESRS EIA proc. No. 111/2004 imposes an obligation on any regional organs empowered in order not to issue licenses without the approval of the regional environmental protection Utility, such obligations are rarely observed and the regional investment agency issues such licenses to investors without the approval of the regional EIA organ to that effect. The same is also true for regional organs which are empowered to carry out public projects by themselves in the region. Even if, institutions like the regional water bureau and rural road authority are required to carry out their responsibilities in close coordination with the regional environmental organ, such coordination is rarely evident. Absence of any standard that EIA consultants should meet while preparing EIA documents and lack of detail laws enabling effective public participation are also some of the major challenges facing the region in order not to effectively integrate environmental considerations into the development aspiration of the region. Hence, implementation of EIA in the region calls for addressing the aforementioned challenge through adoption of detail laws and capable institutions.

\section{Conflicts of Interest}

The author declares no conflicts of interest regarding the publication of this paper.

\section{References}

Abaza, H. et al. (2004). Environmental Impact Assessment and Strategic Environmental Assessment: Towards an Integrated Approach. New York: UNDP.

Alam, S. (2008). Sustainable Development and Free Trade; Institutional Approach. Abingdon-on-Thames: Routledge, Taylor \& Francis Group. https://doi.org/10.4324/9780203936061

Bodensky, D. (2010). The Art and Craft of International Environmental Law. Cambridge: Harvard University Press.

Ethiopian Environmental Impact Assessment Proclamation (2002). Proc. No. 299/2002.

Ethiopian Environmental Protection Organs Establishment Proclamation (2002). Proc. No. $295 / 2002$.

Federal Democratic Republic of Ethiopia Constitution (1995). Proclamation No. 1/1995, 1st Year No. 1, Addis Ababa, 21st August.

International Association for Impact Assessment (IAIA) (1999). Principle of Environmental Impact Assessment Best Practice.

Justice and Environment (2008). Good Examples of EIA and SEA Regulation and Practices in Five European Union Countries.

Sands, P. (2003). Principles of International Environmental Law (2nd Ed.). Cambridge: Cambridge University Press. https://doi.org/10.1017/CBO9780511813511 
Singh, G. (2007). The Inception and Evolution of Environmental Impact Assessment in the World and in India and to Analyze and Comment upon the Environment Clearance Process in the Country.

Teklemichael, Y. (2008). Current Status of the Environmental Impact Assessment System in Ethiopia. UNEP EIA Training Resource Manual.

Tesfaye, A. (2012). Environmental Impact Assessment and Monitoring under Ethiopian Law. Haramaya Law Review, 1, 103-124.

The Environmental Policy of Ethiopia (1997).

The Somali Regional State Environmental Impact Assessment Proclamation (2004). Proc. No. 111/2004.

The Somali Regional State Environmental Protection Natural Resources and Energy Development Utility Establishment (2003). Proc. No. 92/2003. 